\title{
GEOTHERMAL RESOURCES OF THE ALEUTIAN ARC
}

By Roman J. Motyka, Shirley A. Liss, Christopher J. Nye, and Mary A. Moorman

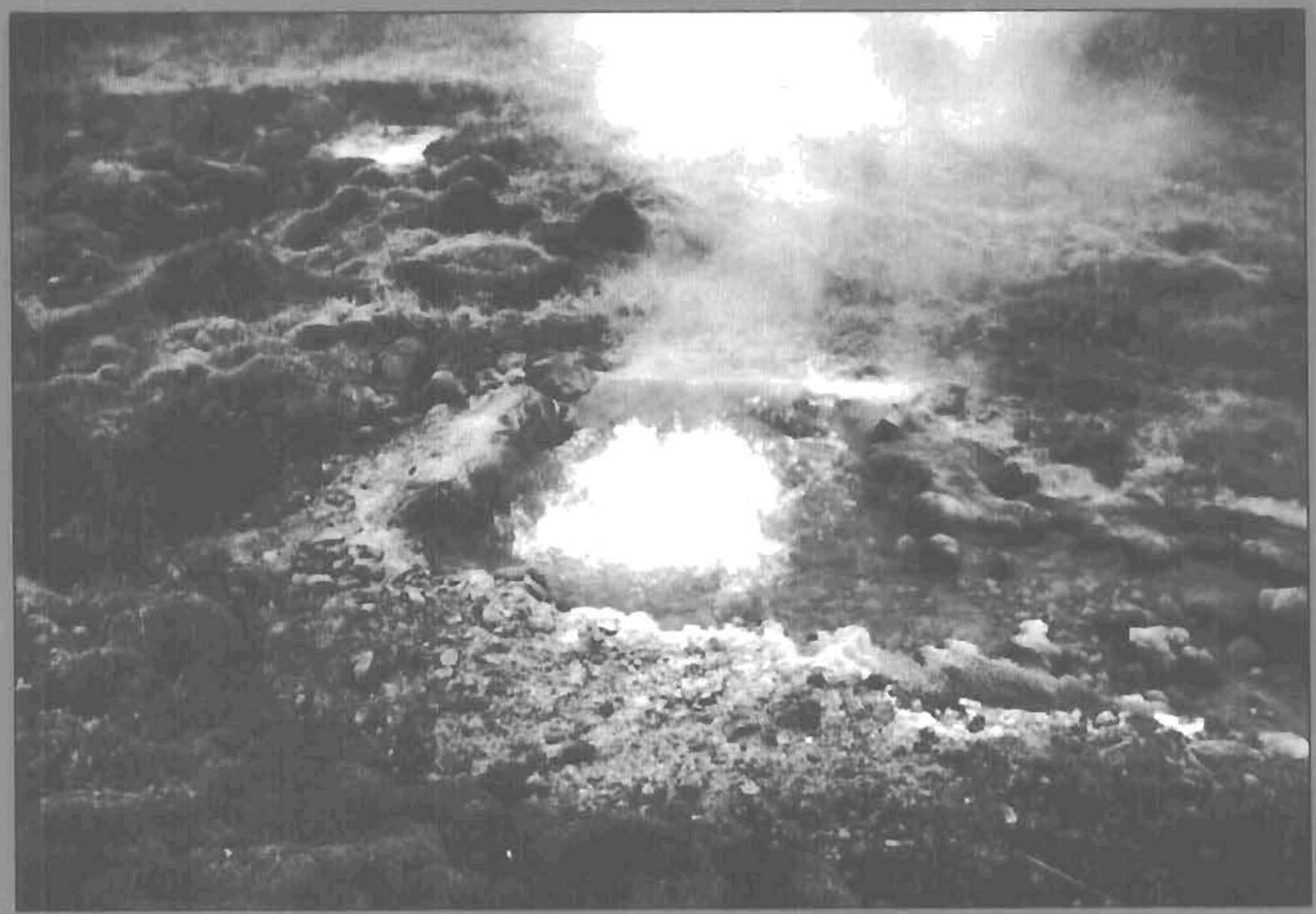

Professional Report 114

Published by

STATE OF ALASKA

DEPARTMENT OF NATURAL RESOURCES

DIVISION OF GEOLOGICAL \& GEOPHYSICAL SURVEYS

1993

Alaska Deparment of
RESOUATURAL 


\title{
GEOTHERMAL RESOURCES OF THE ALEUTIAN ARC
}

\author{
By Roman J. Motyka, Shirley A. Liss, Christopher J. Nye, and Mary A. Moorman
}

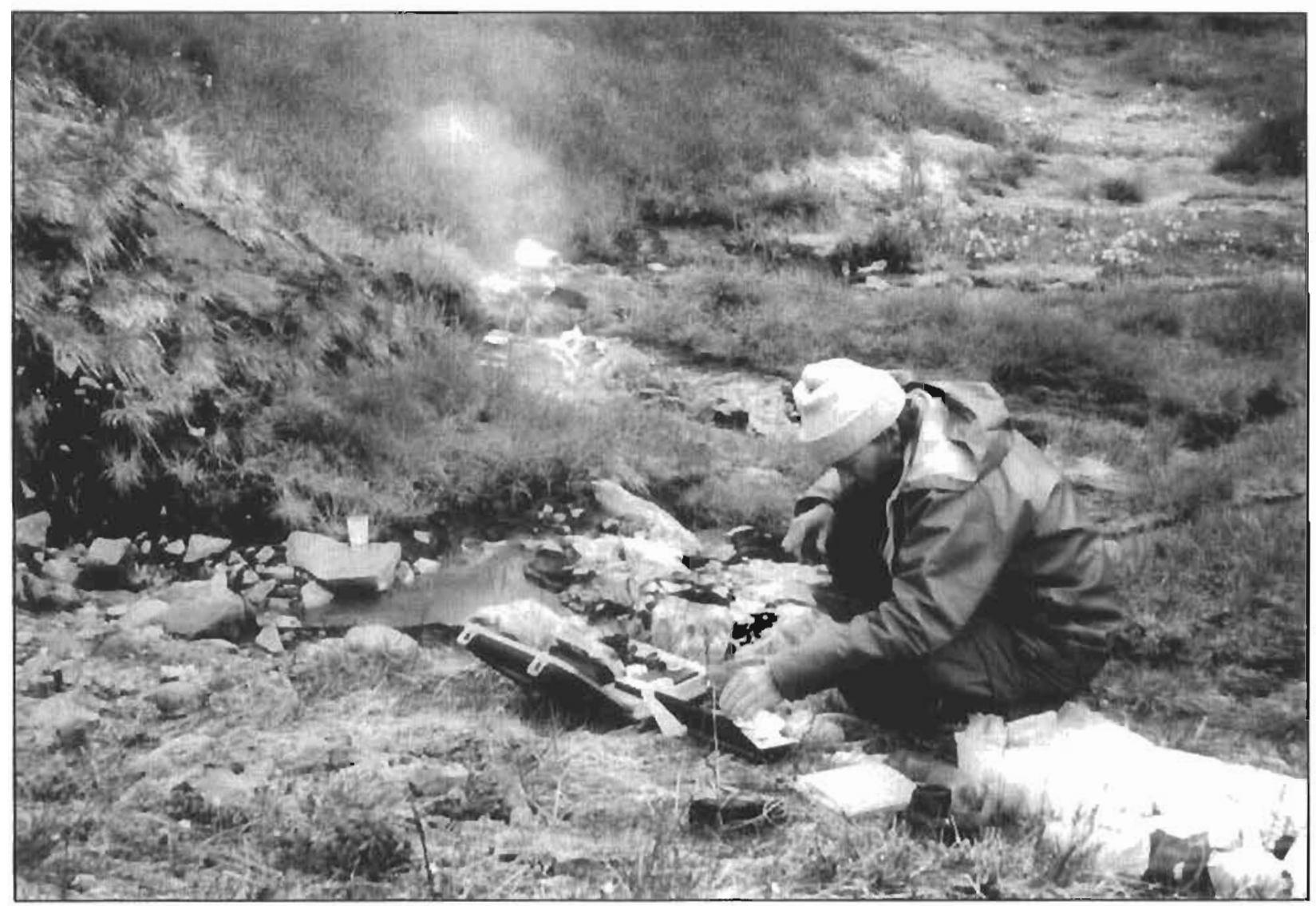

Roman Motyka sampling an upper Glacier Valley hot spring in the Makushin geoshemul area. Photo by Stirley Liss.

Professional Report 114 Division of Geological \&

Geophysical Surveys

Cover photo: "Old Faillyul" of the Geyser Bight geothermal resource area. Whenever is has been observed (1870, 1948, 1980, and 1988), spring G8, shown here at maximum activity, has had an eruption cycle of Fairbarks, Alaska 12 minutes. Pholo by Shirley Liss. 


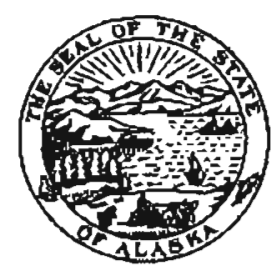

STATE OF ALASKA

Walter J. Hickel, Governor

DEPARTMENT OF NATURAL RESOURCES

Harry A. Noah, Commissioner

\section{DIVISION OF GEOLOGICAL \& GEOPHYSICAL SURVEYS Thomas E. Smith, State Geologist}

Division of Geological \& Geophysical Surveys publications can be inspected at the following locations. Address mail orders to the Fairbanks office.

\section{Alaska Division of Geological \\ \& Geophysical Surveys}

794 University Avenue, Suite 200

Fairbanks, Alaska 99709-3645

BImer E. Rasmuson Library

University of Alaska Fairbanks

Fairbanks, Alaska 99775-1005
University of Alaska Aacborage Library 3211 Providence Drive

Anchorage, Alaska 99508

Alaska Resource Library

222 W. 7th Avenue

Anchorage, Alaska 99513-7589

Alaska State Library

State Office Building, 8th Floor

333 Willoughby Avenue

Juneau, Alaska 99811-0571

This publication released by the Division of Geological \& Geophysical Surveys, was produced and printed in Fairbanks, Alaska, by Graphic North Printing, at a cost of \$14 per copy. Publication is required by Alaska Statute 41, "to determine the potential of Alaskan land for production of metals, minerals, fuels, and geothermal resources; the location and supplies of groundwater and construction materials; the potential geologic hazards to buildings, roads, bridges, and other installations and structures; and shall conduct such other surveys and investigations as will advance knowledge of the geology of Alaska." 


\section{CONTENTS}

\begin{tabular}{|c|c|c|c|}
\hline \\
\hline \multicolumn{3}{|c|}{ Regional geology } & \\
\hline Volcanoes & 4 & & \\
\hline \multicolumn{3}{|c|}{ Bydrothermal systems } & \\
\hline \multicolumn{2}{|c|}{ Thermal waters } & 5 & \\
\hline Fumaroles & 8 & & \\
\hline Resource base & & 10 & \\
\hline Present use & 11 & & \\
\hline Future use & 11 & & \\
\hline Acknowledgmen & & & \\
\hline References cited & & 12 & \\
\hline
\end{tabular}

\section{Figures}

1. Location map of active volcanoes of the Aleutian arc 2

2. Location map of geothermal sites in the Aleutian arc 3

3. Ternary diagram of relarive $\mathrm{Cl}, \mathrm{HCO}_{3}$, and $\mathrm{SO}_{4}{ }^{-2}$ contents of Aleutian arc thermal waters based on weight 6

4. Ternary diagram of relative $\mathrm{Na}^{+}-\mathrm{K}^{+}-\mathrm{Mg}^{+2}$ contents of Aleutian arc thermal waters based on weight 7

5. Plot of stable isotope composition of meteoric waters in the Aleutian arc. Standard mean ocean water (SMOW), Bering Sea waters, Gulf of Alaska waters, and Craig (1961) meteoric waterline shown for comparison 9

6. Plot of stable-isotope composition of thermal waters in the Aleutian arc. Craig (1961) meteoric waterline shown for comparison 9

\section{Tables-See sheet 4 for tables $1-8$}

1. Locations of geothermal sites in the Aleutian arc, from west to east. Thermal manifestations listed in order of importance

2. Quaternary volcanoes of the Aleutian arc

3. Water chemistry, isotopic analyses, and geothermometry of thermai waters in the Aleutian are

4. Chemistry and geothermometry of gases emitred from geothermal fumarole fields and chloride thermal spring systems in the Aleutian arc

5. Chemistry of gases emitted from fumaroles associated with volcanic vents in the Aleutian arc

6. Isotopic analyses of gases emitted from geothermal fumarole fields, thermal springs, and fumaroles associated with volcanic vents in the Aleutian arc

7. Estimates of reservoir temperatures, volumes, and energy stored in identified hydrothermal systems

8. Additional sites suspected of having hydrothermal systems

\section{Sheets-In pocket}

1. Geothermal Resources of the Aleutian Arc, Alaska, Part 1-Western Arc

2. Geothermal Resources of the Aleutian Arc. Alaska, Part 2-Central Arc

3. Geothermal Resources of the Aleutian Arc, Alaska, Part 3-Eastern Arc

4. Geothermal Resources of the Aleutian Arc, Alaska, Part 4 Supplemental data 


\title{
GEOTHERMAL RESOURCES OF THE ALEUTIAN ARC
}

\author{
by Roman J. Motyka, Shirley A. Liss, Christopher J. Nye, and Mary A. Moorman
}

\section{INTRODUCTION}

Quaternary Aleutian volcanism extends for over $2,500 \mathrm{~km}$, from Buldir Island on the west to Mount Hayes on the east (fig. 1). This belt of volcanic activity lies immediately north of the Aleurian trench, a convergent boundary between the North American and Pacific lithospheric plates. The convergence of these plates has produced one of the most seismically active zones in the world.

Active volcanic systems, shallow, magmatically heated rock, and deep fracture and fault systems have combined to create favorable settings for the development of hydrothermal systems. We have tentatively identified at least 56 sites in the Aleutian arc (fig. 2) where surface expressions of these hydrothermal systems, such as thermal springs and fumaroles, are found (table 1, sheet 4). Many of these sites were first reported by Waring (1917) and later summarized in Miller (1973), White and Williarns (1975), Markle (1979), Muffler (1979), Tumer and others (1980), aod Motyka and others (1983a).

This report is based on studies conducted by the Alaska Division of Geological \& Geophysical Surveys (DGGS) between 1980 and 1988, frequendly in cooperation with investigators from the University of Alaska Fairbanks. Our earlier reconnaissance studies concentrated on the geochemistry of thermal spring waters and fumaroles. Later site-specific studies included geological and geophysical surveys and additional fluid geochemistry investigations. Exploratory geothermal wells were drilled at Makushin and Summer Bay on northem Unalaska Island.

Our initial survey (1980) covered the area between Atka Island in the central Aleutians and Becharof Lake on the Alaska Peninsula (Motyka and others, 1981). We extended this coverage west to Adak Island in 1981 (Motyka, 1983) and east to Mount Spurt in 1982. Several sites reported but not substantiated by Waring could not be found by DGGS and therefore are not included in this report (Motyka and others, 1981). Some sites not previously reported, or only briefly mentioned, were investigated by DGGS and are described on the map plates. We did not visit sites west of Adak Island or many of the more remote sites between Adak Island and Mount Spurr. Information on these sites was obtained from published and unpublished sources. We maintaio a bibliography of all references relevant to geothermal resources in Alaska. The bibliography is periodically updated and is available to the public (Liss, Motyka, and Nye, 1988).

\section{REGIONAL GEOLOGY}

This summary of the geologic setting of the Aleutian arc is taken largely from Kienle and Nye (1990). Aleutian arc volcanism is the result of active subduction of the Pacific lithospheric plate beneath the North American lithospheric plate. The 3,400-kmlong Aleutian trench that extends from the northem end of the Kamchaska trench to the Gulf of Alaska marks the boundary between the two plates. The Quatemary Aleutian arc, which spans about 2,500 km of the Alaska mainland and the Aleutian Islands, is built on continental crust in the east and on oceanic crust in the west. The easterm and westem parts of the arc are divided by the Bering Sea continental shelf, which intersects it near Unalaska, Akutan, and Unimak Islands. The volcanic front is sharp and closely aligned with the 100-km depth contour to the Wadati-Benioff zone (Jacob, 1986; Kienle and others, 1983).

The island-forming Quaternary volcanoes of the oceanic part of the arc were built on the Aleutian Ridge, which rises $3,000 \mathrm{~m}$ above the Bering Sea floor to the north and more than $6,000 \mathrm{~m}$ above the Aleutian trench to the south. Scholl and others (1987) describe three rock sequences that record the major evolutionary growth of the Aleutian Ridge:

(1) Arc volcanism in early to middle Eocene time ( 55 to $50 \mathrm{Ma}$ ) formed most of the ridge. The lower series consists of igneous and volcaniclastic basement rocks.

(2) Growth by volcanism subsided during Oligocene and Miocene time, when erosional processes buried the ridge flanks with thick marine sedimentary units. Plutonic activity increased during Oligocene through early Miocene time ( 35 to $8 \mathrm{Ma}$ ).

(3) Pliocene and Quaternary age (younger than 5.3 Ma) slope-mantling and crustal basin sedimentary 


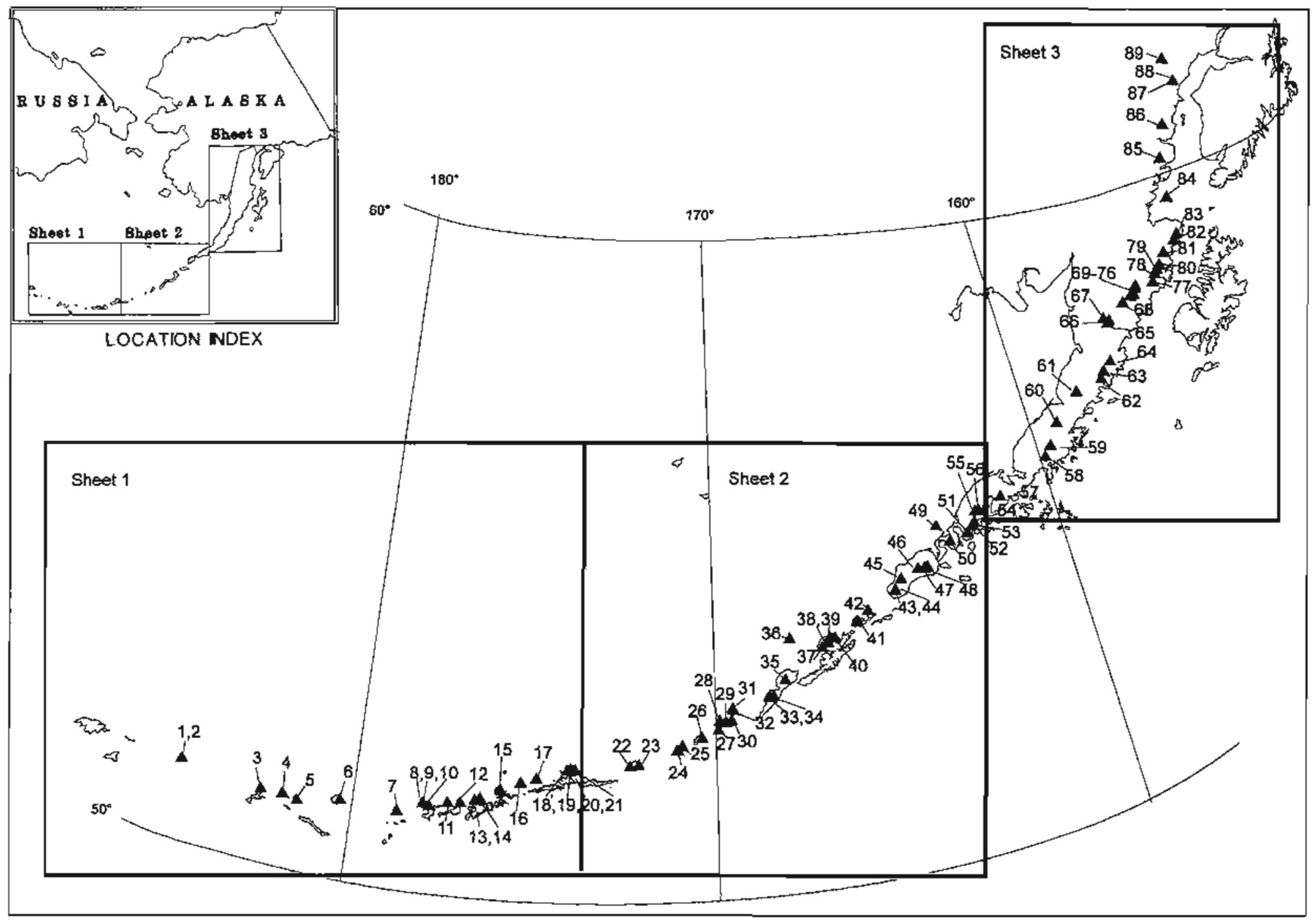

Pigure 1. Active volcanoes of the Aleutian arc. Numbers keyed to table 2, sheet 4. 


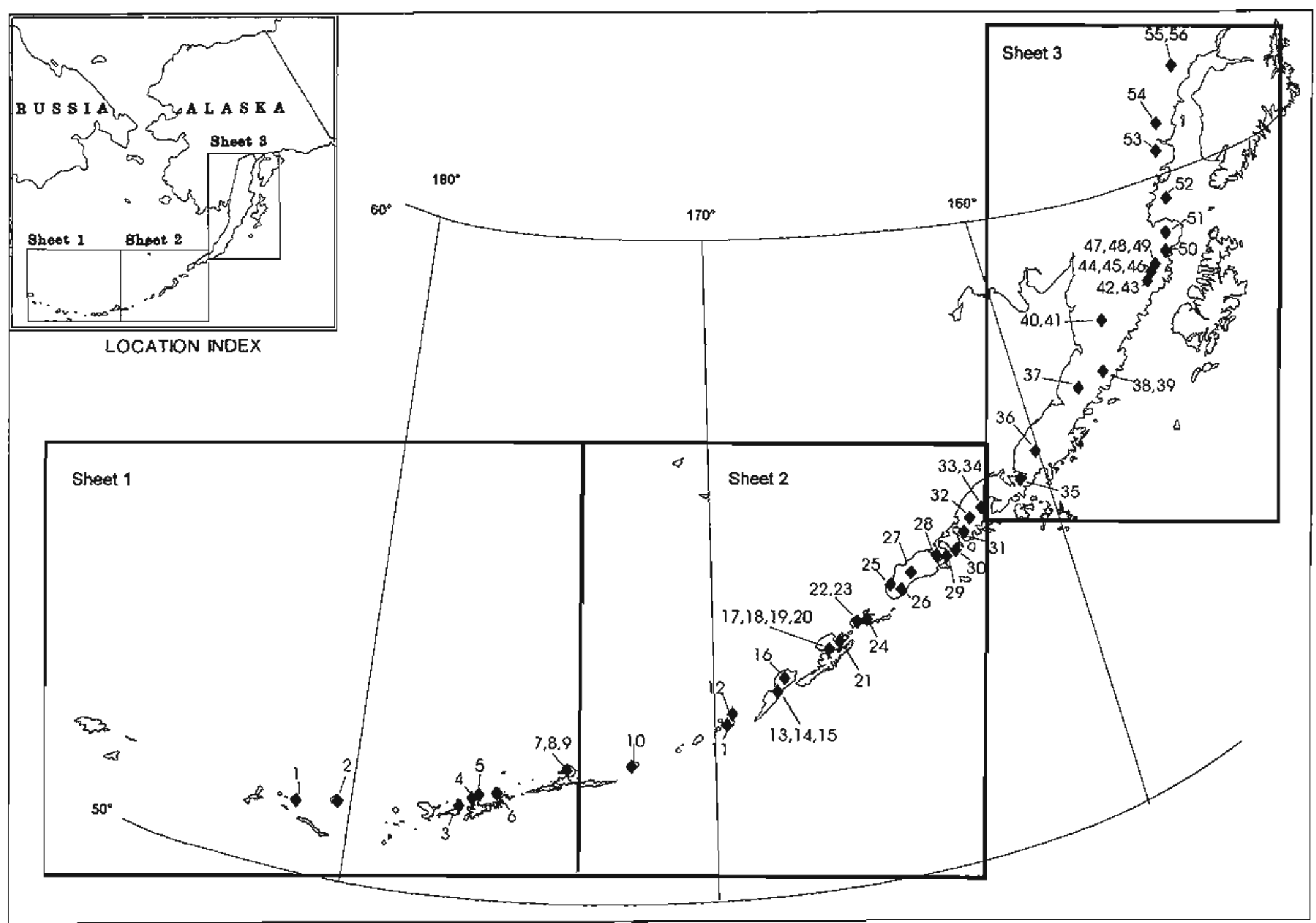

Figure 2. Geothermal sites in the Aleutian anc. Site numbers are keyed to table 1, sheet 4. 
sequences that unconformably overlie the older units form the upper series. Regional subsidence and block faulting affected the ridge crest in late Cenozoic time. Subsequent wave erosion created a prominent summit platform. The Quatemary volcanic belt developed near the northern edge of this platform.

Whereas no terrestrial rocks older than Tertiary bave been found in the oceanic part of the arc, tertestrial rocks of Mesozoic and Paleozoic age make up the basement of the continental part of the arc on the Alaska Peninsula and in the Cook Inlet region (Burk, 1965; Beikman, 1980).

\section{VOLCANOES}

The Aleutian arc includes 89 Quaternary volcanoes, of which 44 have been historically active (Simkin and others, 1981) (table 2, sheet 4). At least 21 of the Quaternary volcanic centers bave calderas (Miller and Smith, 1987), and as many as 19 of these may have formed in Holocene time. Aleutian arc volcanoes are intimately related to the subduction of the Pacific Plate beneath the Nortb American Plate. Material from the subducted slab mixes with material from the astherospheric mantle to produce primary magmas. However, the relative distribution is unknown.

Aleutian magmas have major and trace element and isotopic compositions broadly typical of relatively mature arcs built on oceanic or thin continental crust (Kienle and Nye, 1990). They are dominantly redium potassium basalts through dacites with both calc-alkaline and tholeitic affinities. Rhyolite is volumetrically minor and occurs as glass shards, ash flows, and small pods and domes on the flanks of a few volcanoes. Aleutian volcanic rocks are typically porphyritic, with plagioclase almost always dominant. Mafic lavas usually contain olivine and clinopyroxene phenocrysts, whereas intermediate and silicic lavas usually contain orthopyroxene and clinopyroxene. Amphibole phenocrysts are less common, but do occur throughout the compositional range of Aleutian calc-alkaline magmas. Biotite, which is even more rare, has been reported from a few eruptive centers.

Magmas from the eastem part of the are are dominantly calc-alkaline andesite; tholeiitic magmas are rare. Magmas from the central part of the are are dominantly tholejitic basalt and basaltic andesite. The central part of the arc also contains the most voluminous volcanoes. Volcanoes in the westerm part of the arc erupt calc-alkaline and tholeiitic basalt, basaltic andesite, and andesite.

Table 2 (sheet 4) lists known Quatemary volcanoes of the Aleutian arc and provides information on volcano elevation, current morphology, and eruptive history. It also includes a qualitative estimate of the potential for the presence of a developable hydrothermal resource. Numbers are keyed to the map sheets.

\section{HYDROTHERMAL SYSTEMS}

Thermal springs, fumaroles, and heated ground are the surface manifestations of subsurface hydrothermal systerns. In such systems, heat is transported primarily by convective circulation of fluids (usually water or steam) rather than by thermal conduction through solid rock. Hydrothermal systems have been classified as either hot-water or vapordominated, depending on the dominant pressurecontrolling fluid in fractures and pores. Most explored systems in the world are hot-water dominated (White and Williams, 1975). Vapor-dominated systems are relatively rare. Although fumarole fields are associated with many Aleutian arc thermal sites, these steam-phase manifestations are probably surface expressions of shallow, vapor-dominated systems created by boiling of a deeper hot-water system (for example, Makushin [Motyka and others, 1983b; Motyka and others, 1988]). Hot-water convection systems are divided into three categories based on reservoir temperatures: high temperature $\left(>150^{\circ} \mathrm{C}\right)$; intermediate temperature ( 90 to $150^{\circ} \mathrm{C}$ ); and low temperature $\left(<90^{\circ} \mathrm{C}\right)$ (Muffler, 1979).

The temperature of the hottest spring or fumarole, the estimated convective heat discharged at the surface by spring flow, the total dissolved solids in the waters from the principal spring, and the estimated reservoir temperature based on chemical geothermometry for each thermal site are shown on the map sheets. A dash indicates no data for that entry. Site numbers are keyed to table 1 (sheet 4 ). which lists location by geographic coordinates. In addition, brief site descriptions accompany the diagrams. Larger scale iusets $(1: 250,000)$ are provided for several areas that were more intensively investigated.

Chemical geothermometers are based on temperature-sensitive chemical reactions in bydrothermal fluids and are commonly used to estimace subsurface temperatures at sites where drilling data are not available. These reactions may control either the absolute amount of an element (for 
example, silica), the relative concentrations of elements (for example, cations), or the fractionation of jsotopes. The estimated reservoir temperatures derived from geothermometry calculations may represent actual subsurface temperatures if several assumptions about the nature of an individual hydrothermal system are satisfied. For a review of chemical and isotopic geothermorneters, see Fournier (1981).

\section{THERMAL WATERS}

Only four thermal-spring sites in the Aleutian arc are located near population centers. These include Kiguga (site 4, sheet 1) and Andrew Bay (site 5. sheet 1), near the Adak naval station; Summer Bay (site 21, sheet 2), near Unalaska village; and Hot Springs Bay (site 23, sheet 2), near Akutan village. False Pass (site 28, sheet 2) and Port Moller (site 35, sheet 3 ) thermal springs are located within $12 \mathrm{~km}$ of small villages. Sites 7,8 , and 9 (sheet 1 ) on northeast Atka Island lie about $15 \mathrm{~km}$ north of Atka village; the Makushin geothermal area (site 20, sheet 2) is located $20 \mathrm{~km}$ west of Unalaska village; while Nikolski, the closest village to Geyser Bight (site 13, sheet 2), is located $40 \mathrm{~km}$ west of this geothermal area. The remaining thermal springs are located in remote arees, commonly near tidewater or on the flanks of active volcanoes.

Table 3 (sheet 4) provides chemical analyses of water from the principal thermal spring, geothermal well, or crater lake at each visited site. Plots of major anions $\left(\mathrm{Cl}^{-}, \mathrm{HCO}_{3}{ }^{-}\right.$, and $\left.\mathrm{SO}_{4}{ }^{-2}\right)$ provide a convenient method of classifying thermal waters based on the dominant anion (fig. 3 ) and can also provide insights into the origin of the thermal water. In figure 3, compositional ranges are indicated for several typical thermal-water groups (Giggenbach and Goguel, 1989). Acid "volcanic" waters are formed when volcanic crater lakes or shallow groundwater absorb high-temperature, sulfur- and chlorite-rich volcanic gases (for example, sites 48, 51, and 56a, sheet 3 ). Sulfate-rich "steam-heated" waters form when shallow groundwater absorbs steam, hydrogensulfide, and other gases produced by boiling of a deeper hot-water system (for example, sites $6,7,8$, and 9 , sheet 1 ; site 22, sheet 2). Neutralization of these generaily acidic waters through subsurface waterrock-gas interactions can produce waters enriched in bicarbonate (for example, sites 19 and 20, sheet 2). High-sulfate, steam-heated waters are usually only encountered at higher elevations of a geothermal field. Geothermometers are generally not suifable for application to these steam-heated waters. Neutral, low-sulfate, high-chloride waters that lie along or near the $\mathrm{Cl}^{-}-\mathrm{HCO}_{3}{ }^{-}$axis, close to the $\mathrm{Cl}^{-}$comer (fig. 3) are considered to be directly related to deep thermal waters and are best suited for estimating reservoir temperatures. High bicarbonate concentrations indicate the waters are derived from the margins of a thermal area, whereas waters containing near-equal proportions of anions are probably of mixed origin. Considerable caution is required in applying geothermometers to these waters.

The $\mathrm{Na}^{+}-\mathrm{K}^{+}-\mathrm{Mg}^{+2}$ diagram (fig. 4) and its application to geothermal systems are described by Giggenbach (1988). The "full-equilibrium" curve represents water compositions in full equilibrium with the mineral system albite-poiassium feldsparmuscovite-clinochlore-silica at the temperatures indicated. The boundary between partially equilibrated and immature waters is somewhat arbitrary and serves only as a rough guide. The isotherms correspond to equilibrium between the pairs potassium-sodium and potassium-magnesium at various temperatures as derived by Giggenbach (1988). Magnesium concentrations in thermal waters are highly temperature dependent; hotter remperatures favor magnesium depletion through hydrothermal reactions. In mature thermal waters, magnesium is commonly present in trace amounts only.

Water from Makusbin Well ST-1 (site 20a, sheet 2) plots close to the full equilibrium line, wbile Geyser Bight thermal spring waters (sites 13a,b,c, sheet 2) and several other chloride thermal spring waters tread toward the magnesium comer in the partial-equilibrium field. This trend reflects the greater speed with which the potassium and magnesium concentrations adjust to changes in temperature as compared with potassium and sodium as the water ascends to the surface. Several thermal waters plot in the compositional range marked "immature waters" near the magnesium corner. For some, magnesium may be added by dissolution of minerals in the shallow environment as the waters cooled conductively or mixed with cold groundwater (for example, sites 23,28, and 32, sheet 2). The remaining waters analyzed in this study are typically either acid (sites $6,7,8$, and 9 , sheet 1 ; sites 22,48 , 51 , and $56 \mathrm{a}$, sheet 3 ) or carbon-dioxide-rich (sites 18 and 19 , sheet 2 ; sites 40,44 , and $56 \mathrm{~b}$, sheet 3 ). 
Because these waters are usually not in chemical equilibrium application of geothermometers to these "immature" thermal waters may be inappropriate and interpreting temperatures based on the water's chemical composition must be carefully considered.

We have applied silica and several cation geothermometers to Aleutian arc thermal water chemistry (table 3, sheet 4) (see Fournier, 1981, for a review of geothermometry). These geothermometers are most reliabie for "chioride" thermal waters and are less certain for "mixed and peripheral" waters. They are probably not valid for steam-heated and "acid-volcanic" waters. The potassium-magnesium geothermometer is useful for evaluating lowtemperature waters (Giggenbach, 1988), while the magnesium-lithium geothermometer was developed specifically for sedimentary formation waters (Kharaka and Mariner, 1989). The rate of the sulfate- water oxygen isotope exchange reaction is very slow compared with silica solubility and cation exchange reactions (McKenzie and Truesdell, 1977). Therefore, temperatures predicted by the sulfate-water oxygen isotope geothermomeler serve as potential indicators of temperatures at greater depths.

The results of stable isolope analysis of 94 meteoric stream waters and precipitation collected in the Aleutian arc are shown in figure 5. Linear regression analysis shows that the best fit to these points is nearly identical to Craig's meteoric water line (1961). Also plotted are values for Bering Sea waters, Gull of Alaska waters, and Standard mean ocean water (SMOW). Values for stable isotope compositions of Aleutian arc thermal waters are plotted in figure 6 . The coincidence of most thermalwater values with meteoric-water values indicates that meteoric waters constitute the primary source of recharge for Aleutian arc hydrothermal systems. Some

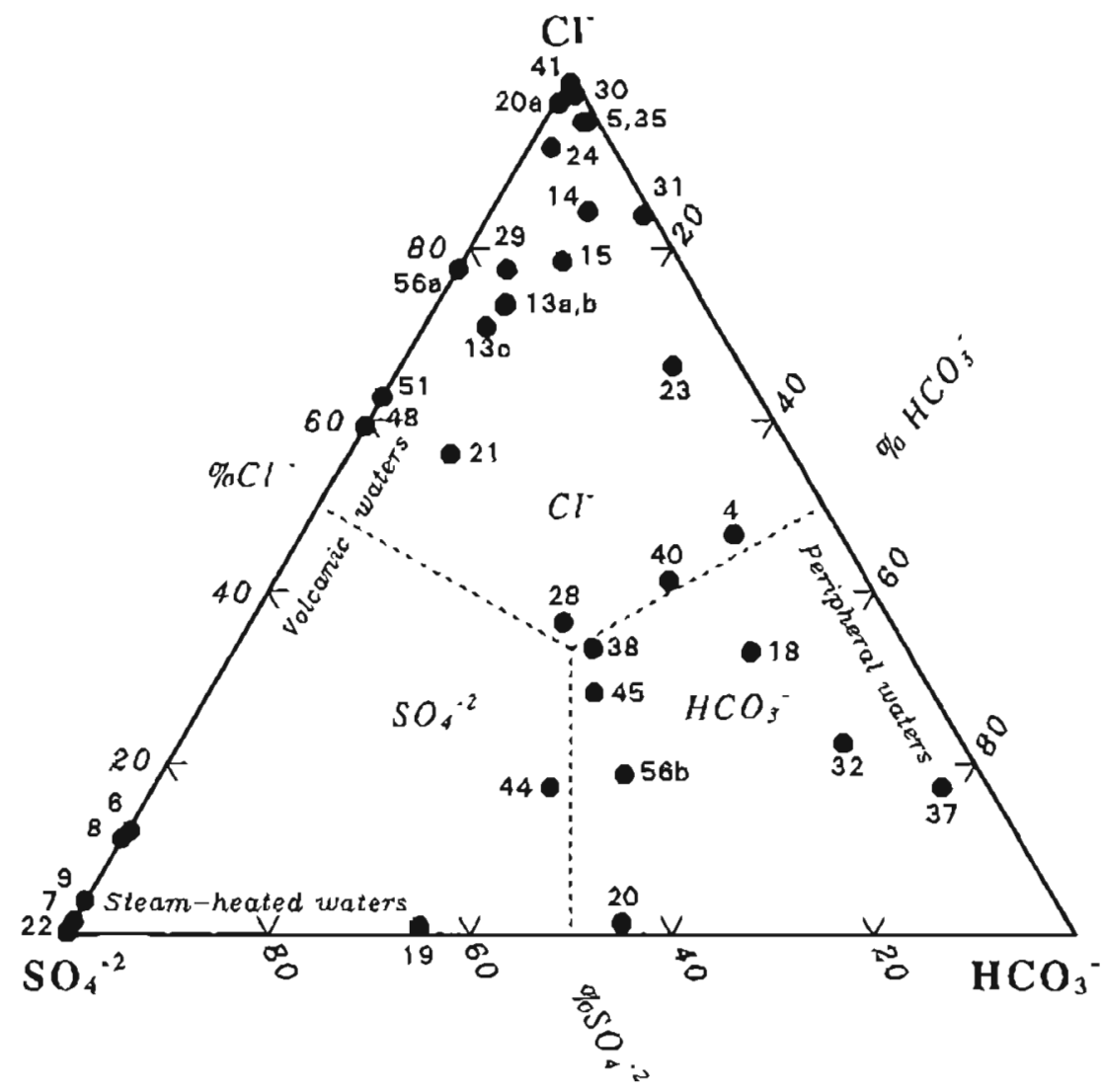

Figure 3. Relative $\mathrm{Cl}^{-}, \mathrm{HCO}_{3}{ }^{-}$, and $\mathrm{SO}_{4}^{-2}$ contents of Aleutian arc thermal waters on weight ( $\mathrm{mg} / \mathrm{kg}$ ) basis (afier Giggenbach and Goguel, 1989). Numbers refer to thermal-spring sites shown on sheets and listed in table l(shees 4). 
thermal waters have $8^{18} \mathrm{O}$ displaced +1 to +2 per mil from local meteoric water values (for example, sites 13, 20, sheet 2; fig. 6). Such positive shifts have been attributed to oxygen- 18 exchange between the deeply circulating meteoric waters and reservoir wallrocks. The degree of shift depends on temperature and on the rock/water ratio (Truesdell and Hulsion, 1980). Springs 5, 41, and pertiaps 40 may have been partially derived from connate brines. Such waters are typically eariched in deuterium and oxygen-18 (Truesdell and Hulston, 1980). The relatively heavier stable-isotope composition of the boiling acid-sulfate waters at springs 7 and 22 is probably attriburable to evaporative effects: the lighter isotopes fractionate into the vapor phase.
Analysis of gas emissions collected from chloride thermal spring sites in the Aleutian are are given in table 4 (sheet 4). Thermal-spring gases were collected by immersing a fuanel connected to an evacuated flask over a train of gas bubbles emerging from the hot spring or pool. When water in the funnel was displaced by gases, a stopcock was opened and the gases were collected in the evacuated flasks. Methane is the primary component at Cold Bay (site 31, sheet 2) and Port Moller (site 35, sheet 2), whereas carbon-dioxide predominates at Andrew Bay (site 5 . sheet 1), lower Glacier Valley (site 18, sheet 2), and Gas Rocks (site 41, sheet 3). Nitrogen is the major component at the remaining springs. Tbe nitrogenargon ratios at most sites are close to the atmospheric

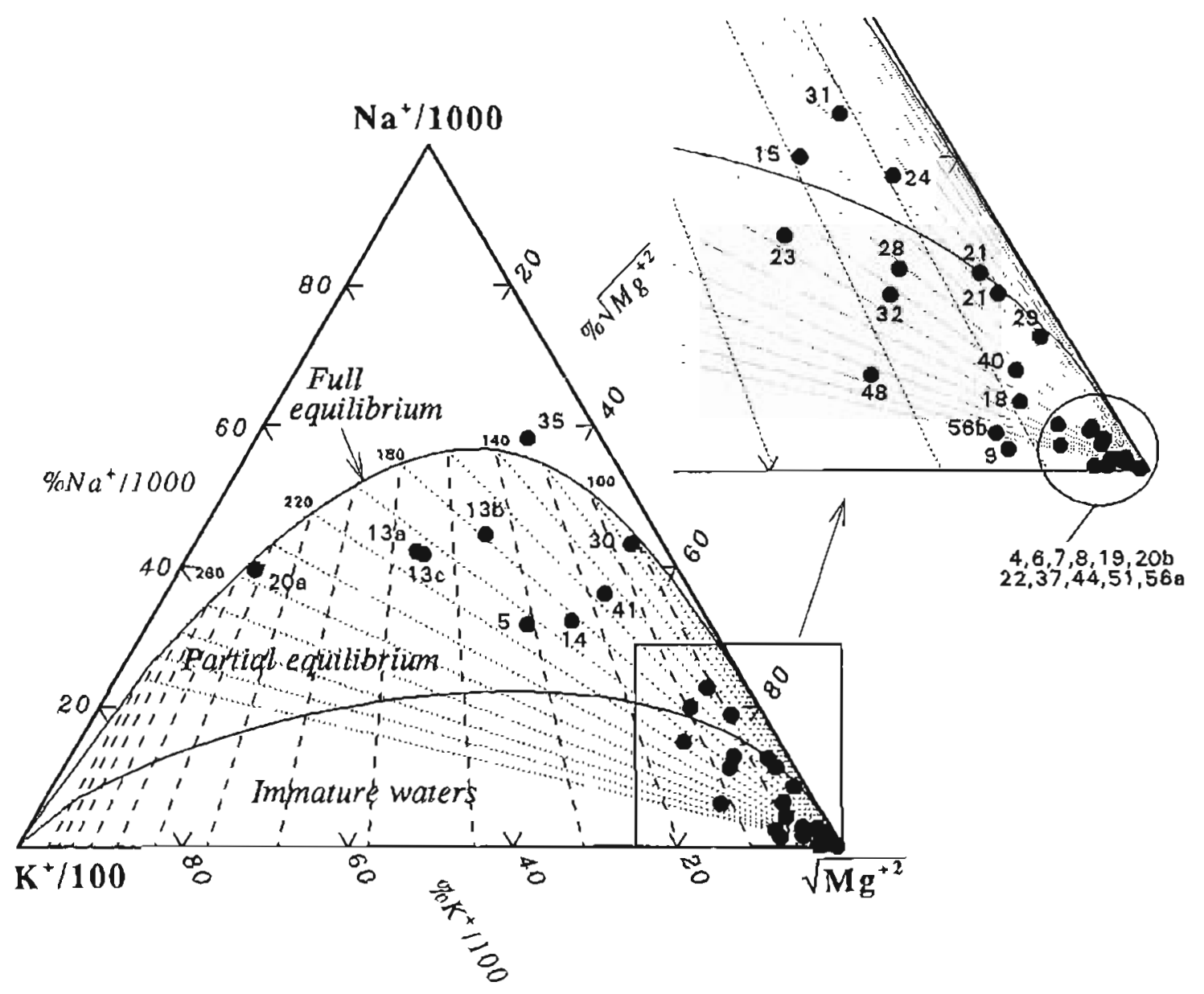

Figure 4. Relative $\mathrm{Na}^{+}-\mathrm{K}^{+}-\mathrm{Mg}^{+2}$ contents of Aleutian arc thermal waters on weight (mg/kg) basis (after Giggenbach and Goguel, 1989). Na-K-Mg temperatures from Giggenbach (1988). Numbers refer to thermal-spring sites shown on sheets and listed in table 1 (sheet 4). 
ratio $(\sim 84)$ or lie between the air ratio and airsaturated groundwater $(-34)$ ratios, indicating that nitrogen and argon are largely derived from air. Because of oxidation reactions, oxygen is usually only present in very minute quantities in equilibrated hydrothermal fluids. Its presence in measurable amounts indicates air contamination. Except for Hot Springs Bay (site 23, sheet 2), the gas emissions are commonly depleted in hydrogen sulfide and hydrogen when compared with fumarolic gases (table 4, sheet 4). Oxidation and other reactions probably removed these gases from the thermal water, and methane is probably of thermo-biogenic origin. We suspect that the carbon dioxide is mostly derived from magmatic sources although some carbon dioxide may be thermo-biogenic in origin.

Most Aleutian arc chloride thermal springs probably originate as meteoric waters that circulate along fracture and fault systems produced by tectonic forces associated with the collision of the Pacific and North American lithospheric plates. Waters that circulate through the fractures are heated by thermal conduction from the surrounding rock and, in some cases, by direct absorption of volcanic steam and gases. Near active volcanism, heat is supplied by magmatic sources: at locations farther from volcanoes, heat is supplied by the regional heat flux. Net enthalpy per kilogram of discharge from each spring area was calculated as the difference between the discharge temperature and an assumed reference temperature of $10^{\circ} \mathrm{C}$ at the land surface. The total beat discharged at the surface by thermal springs in the Aleutian arc is conservatively estrmated at $78 \mathrm{MW}$.

\section{FUMAROLES}

Furnaroles are found at numerous geothermal sites in the Aleutian arc. In many cases, they are the dominant surface manifestation of the hydrothermal resource (table 1, sheet 4). We distinguish between "geothermal" and "volcanic" fumaroles primarily by their spatial association with active volcanic vents. In the Aleutain arc, "geothermal" fumaroles typically lie at mid-elevations on the flanks of volcanoes, relatively distant from an obvious volcanic vent. The fumaroles usually occur in clusters that cover several to tens of hectares in area, and commonly are associated with steam-heated or acid-sulfate springs. Hydrothermal alteration is usually widespread and ubiquitous, indicating long-tern fumarolic activity. In some cases, chloride thermal springs may emerge at lower elevations (for example, sites 13, 19, and 22, sheet 2). Aleutian arc "geothermal" fumaroles are iypically at boiling point temperatures. Carbon dioxide is the dominant dry-gas component, and hydrogen sulfide is the only sulfur gas present (table 4, sheet 4). We presume these furnaroles are the surface expressions of boiling, subsurface, liquiddominated hydrothermal systems, although at a few locations in the world such fumaroles reflect deep, vapor-dominated systems (for example, Geysers, California, and Lardellero, Italy). Asthough magma is probably the heat source and probably contributes carbon dioxide, sulfur gases, and halogens to the overlying liquid-dominated hydrothermal systems, "geotbermal" fumarolic gas compositions are controlled by water-gas-rock interactions and boiling within the hydrothermal reservoir.

In contrast, fumaroles associated with volcanic vents are commonly supecheated and may emit sulfur-dioxide and halogen-rich gases (table 5 , sheet 4). Steam content is highly variable, and in some cases sulfur gases equal or exceed carbon dioxide as the dominant dry-gas component. "Volcanic" fumaroles are located on the floors, rims, and flanks of active craters (sites 17, sheet 2; sites 43,51 , and 56, sheel 3 ); on active lava domes (sites 44 and 52, sheet 3); and on the cones and summits of active volcanoes (sites 16 , sheet 2 ; sites 46 , and 47 , sheet 3 ). Their location and correlation with volcanic activity and gas chemistry suggest a more direct connection to magmatic sources with fumarolic compositions controlled by magma- and rock-gas interactions (sites 51 and 52, sheet 3). In some cases, meteoric water may flood and quench the surface of residual magma to create a boiling hydrothermal layer and give rise to "geothermal" gas emissions (sites 17, sheet 2; site 56, sheet 3 ). Although it is unlikely that volcanic vents will be commercially developed for geothermal energy, "volcanic" gas samples provide useful information on the magmatic heal sources that may underlie geothermal systerns and serve as a reference for comparison with "geothermal" gas emissions.

Because oxygen in fumarole gases should be virtually nonexistent, any oxygen detected in our samples is attributed to air contamination. Most "geothermal" and "volcanic" fumaroles have nitrogen-argon ratios that lie between atmospheric $(-84)$ and air-saturated groundwater $(-34)$ ratios, indicating an atmospheric origin for the nitrogen and argon, with oxygen removed in oxidation reactions. 


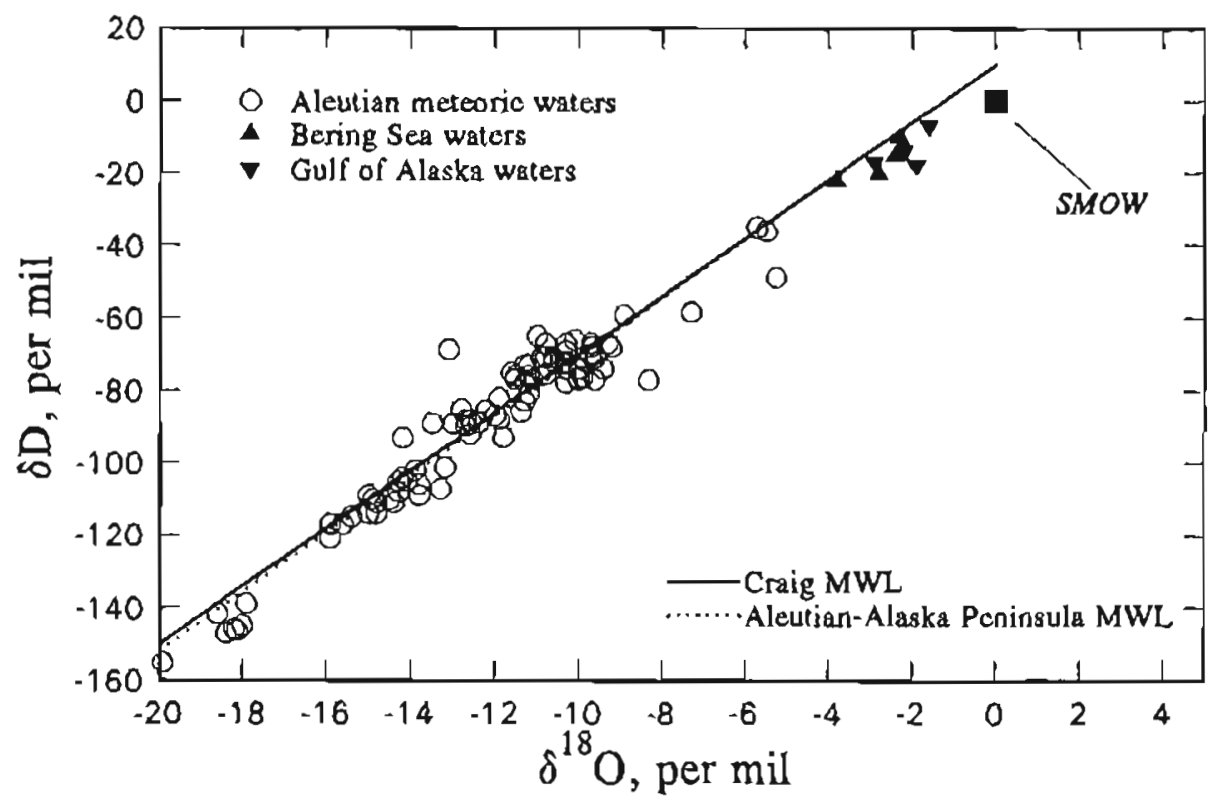

Figure 5. Stable isotope composition of meteoric waters in the Aleutian arc. Standard mean ocean water (SMOW), Bering Sea waters, Gulf of Alaska waters, and Craig (1961) meteoric waterline shown for comparison. Dotted line represents linear regression fit to Aleutian and Alaska Peninsula meteoric water data.

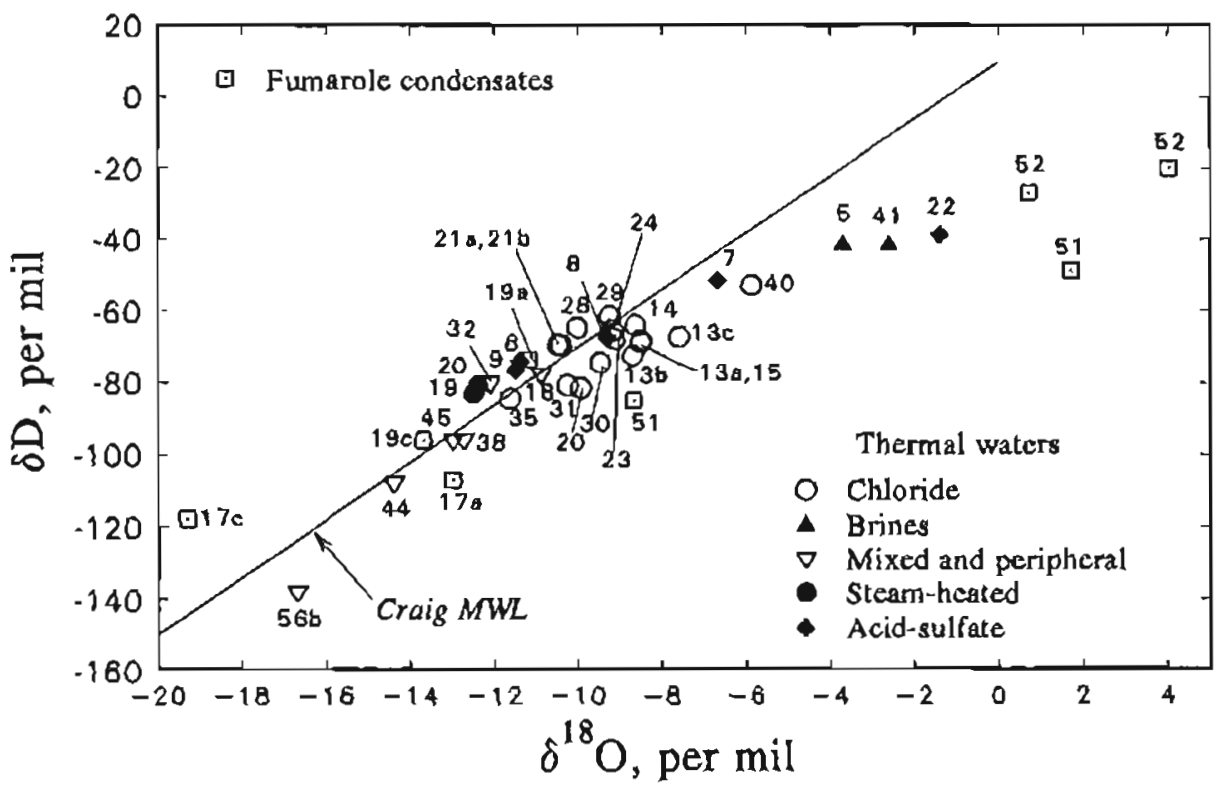

Figure 6. Stable-isotope composition of thermal waters in the Aleutian arc. Craig (1961) meteoric waterline shown for comparison. Numbers refer to thermal-spring sites shown on sheets and listed in lable I (sheet 4). 
In some cases, the nitrogen-argon ratio substantially exceeds the atmospheric ratio. The excess nitrogen may be derived from a magmatic source.

A magmatic influence on the Aleutian arc fumarole fluids is supported by helium isocope ratios, where $\mathrm{R} / \mathrm{Ra}$ is the ratio of ${ }^{3} \mathrm{He} / 4 \mathrm{He}$ in the sample to ${ }^{3} \mathrm{He}^{4} \mathrm{He}$ in the atmosphere (table 6, sheet 4). This ratio ranges from 6.5 to 8.0 for Aleutian arc "volcanic" fumaroles compared to $8 \pm 1$ for mid-ocean-ridge basalts (Poreda and Craig, 1989). Values for Aleutain arc "geothermal" fields range from 2.1 at Port Moller (site 35, sheet 3) to 7.5 at Geyser Bight (site 13, sheet 2). The lower values are probably caused by mixing of varying proportions of crustal helium $(\mathrm{R} R \mathrm{Ra}<0.02)$ with mantle-derived helium.

Although a few sites have isotopic values of $\delta^{13} \mathrm{C}-\mathrm{CO}_{2}$ that lie within the range of mantle-derived carbon dioxide (-4 to -9 per mil), $8^{13} \mathrm{C}-\mathrm{CO}_{2}$ values for most Aleutian arc fumaroles are lighter than mantle carbon dioxide, but lie within the range for marine organic carbon (-7 to -17 per mil; Truesdell and Hulston, 1980; table 6, sheet 4). These ranges allow for the possibility that Aleutian arc fumarolic carbon dioxide is a mixture of mantle carbon dioxide and carbon dioxide derived from marine-organic sources.

Using empirical data, D'Amore and Panichi (1980) devised a gas geothermometer to estimate geothermal reservoir temperatures based on the proportions of carbon dioxide, hydrogen sulfide. hydrogen, and methane in geothermal fumarolic gases. The geothermometer, which assumes a gas-water-rock equilibrium in a hydrothermal system and preservation of this "deep" equilibrium composition in the emergent gases, was applied to geothermal fumarolic gases using an assumed partial pressure for carbon dioxide of 1 bar (table 4, sheet 4). These temperature estimates must be treated cautiously because gas-rock interactions and oxidation reactions with entrained air can affect gas composition, particularly hydrogen and hydrogen sulfide, during fluid ascent and sampling. To circumvent some of the problems of multi-component geothermomters, Giggenbach and Goguel (1989) devised gas geothermometers based on isomolar concentrations of hydrogen and carbon dioxide with respect to argon. Argon was chosen because it is inert and because it is introduced almost exclusively with the metcoric water component that forms the bulk of most geothermal waters. Results of applying the hydrogen-argon and carbon dioxide-argon geothermometers to Aleutian arc geothermal fumaroles are shown in table 4 (sheet 4). Temperatures predicted by these two geothermometers are similar, but generally lower than estimates obtained from the D'Amore and Panichi (1980) geothermometer. The highest temperalures estimated by gas geothermometry are $300^{\circ} \mathrm{C}$ (Milky River, site 9, sheet 1; upper Glacier Valley, site 19. sheet 2).

These geothermal geothermometers were not applied to volcanic vent fumaroles because of uncertainties about the environment of subsurface volcanic gas equilibration. Subsurface temperatures at these sites probably exceed $150^{\circ} \mathrm{C}$. Where sulfide and halogen gases are emirted from fumarolic vents, gas source temperatures probably exceed $350^{\circ} \mathrm{C}$. Methods for reconstructing subsurface volcanic gas assemblages and determining equiliorium temperatures from fumarolic gas compositions have been developed by Reed and Symonds (1992) and Giggenbach (1987). These methods have been applied to Augustine (site 52, sheet 3) 1984 samples (Kodosky and others, 1991: Te-800 $\mathrm{C}$ ); post-eruptive 1986 Augustine gas samples (Symonds and others, 1990; $\mathrm{Te}>1,200^{\circ} \mathrm{C}$ ); and to samples from Katmai National Park (Sheppard and others, 1992; Te $>600^{\circ} \mathrm{C}$ ).

\section{RESOURCE BASE}

We evaluated the Aleutian arc geothermal resource base according to methods developed by White and Williams (1975) and Muffler (1979). Our expanded data base, acquired since 1979, allowed us to identify several hydrothermal systerns that were not reported in earlier assessments of the geothermal resources of the Aleutian arc. At least 14 sites potentially host high-temperature $\left(>150^{\circ} \mathrm{C}\right)$ hydrothermal reservoirs; four sites host intermediatetemperature systems $\left(9010150^{\circ} \mathrm{C}\right)$; and six sites host low-temperature systems $\left(<90^{\circ} \mathrm{C}\right.$; table 7 , sheel 4$)$. Geothermal drilling in 1983 and 1984 confirmed a liquid-dominated hydrothermal resource of at least $195^{\circ} \mathrm{C}$ at Makushin Valley (site 20, sheet 2). Reservoir temperanures for Makushin Valley and the remaining geothernal sices were estimated using applicable geothermometers (table 7, sheet 4). Mean reservoir temperatures are based on the average of minimum, maximum, and most likely temperatures determined by geothermometry, geothermal well temperature (sites 20 and 21, sheet 2), and thermal-spring vent temperature (site 28 , sheet 2) following methods similar to those described in Brook and others (1979). 
At least 20 other sites probably have reservoirs with temperatures $>150^{\circ} \mathrm{C}$ (table 8 , sheet 4 ), but development of these sites is unlikely because they are located on or near active volcanic vents or in national conservation units.

The amount of thermal energy stored in the Accessible Resource Base as defined by Brook and others (1979) is estimated at $42 \times 10^{18} \mathrm{~J}$ for the 14 high-temperature systems; $3.8 \times 10^{18} \mathrm{~J}$ for the four intermediate-temperature systems; and $0.9 \times 10^{18} \mathrm{~J}$ for the six low-temperature systems (table 7. sheel 4). For $\mathrm{T}>90^{\circ} \mathrm{C}$, these estimates are based on an assumed mean reservoir thickness of $1.67 \mathrm{~km}^{3}$ (Mariner and others, 1978). Estimates of reservoir area are based on the surface expression of the geothermal resource. Where a single group of springs or fumaroles are the only evidence of a reservoir, the subsurface reservoir volume is estimated to be $3.3 \mathrm{~km}^{3}$ (Mariner and others, 1978; Brook and others, 1979) and $1 \mathrm{~km}^{3}$ for $T<90^{\circ} \mathrm{C}$ (Sorey and otbers, 1983). Heat energy in the reservoir is referenced $1015^{\circ} \mathrm{C}$ as defined by Brook and others (1979). Welthead thermal energy, available work, electrical energy, and beneficial heat were calculated using methods described in Brook and others (1979). We estimate that the combined 30-yc electric-powerproduction potential for the 14 high-temperature sites $>1,000 \mathrm{MW}$.

A much greater store of geothermal energy resides in shallow magma chambers and hot rock beneath volcanic edifices (table 2 , sheet 4 ), but estimates of the heat content of these magmas are highly speculative. Using estimates of high-level magma-chamber volumes and radiometric ages of the youngest related volcanism. Smith and Shaw $(1975 ; 1979)$ estimate that $12 \times 10^{21} \mathrm{~J}$ of thermal energy remains in Aleutian arc igneous systems. Given the highly speculative nature of estimating igneous-related thermal energy and the improbability that technological advances will allow commercial development of such resources in the foreseeable future, further refinement of these estimates is not justified.

\section{PRESENT USE}

A test well drilled near the head of Makushin Valley (site 20, sheet 2) on northem Unalaska Island, as part of a state-funded geothermal exploration program, successfully produced $195^{\circ} \mathrm{C}$ water from a depth of $590 \mathrm{~m}$ (Republic Geothermal, Inc.. 1983, 1984, 1985; Motyka and others, 1988). Battle
Mountain Gold Company purchased the land and leased the geothermal resource to OESI Power Corporation (formerly Ormat Energy, Inc.). The Alaska Energy Authority has analyzed OESI's plans to develop a $12 \mathrm{MW}$ geothermal power plant at the site. The project would provide base load power to the residents of the city of Unalaska and to the fishing and shipping industry at the international Port of Dutch Harbor. If developed, Makushin Valley would be the first site in Alaska to use geothermal energy to produce electric power.

The state of Alaska has leased two tracts southeast of Mount Spurr to a private company for geothermal development. The lease-holders have announced plans to develop the site for hydroponic gardening, but no action has been taken. During a pilot geothermal-drilling program sponsored by the Alaska Division of Energy and Power Development (now the Alaska Energy Authority), a shallow, warmwater aquifer was delineated at Summer Bay (site 21, sheet 2) at a depth of about $50 \mathrm{~m}$. Unfortunately, the flow rate and resource temperature were too low to use for direct-heat applications.

Several scientific studies have been conducted in Katmai National Park as part of the Katmai Scientific Drilling Project, an interdisciplinary surface and drilling investigation of the 1912 eruption from Novarupta. The surface phase of the investigation has been completed, and plans call for drilling two core holes into the vent and one through the ashflow sheet in 1994-95. The drilling must first be approved by the National Park Service following completion of an Environmental Impact Statement

Little or no development has occurred at thermal sites elsewhere in the Aleutian arc, largely because of their remoteness and the costs associated with developing resources in remote localities. Several thermal-spring areas located near villages are used as recreational sites: Andrew Bay (site 5, sheet 1), Hot Springs Bay (site 23, sheet 2), Port Moller (site 35, sheet 3), and False Pass (site 28, sheet 2). Early historic accounts suggest that thermal springs on northeast Atka Island and on Umnak Island may have been used by native populations for recreational and ceremonial purposes.

\section{FUTURE USE}

Most remote thermal sites in the Aleutian arc will probably remain undeveloped. particularly those located within national conservation units. However. 
in addition to Makushin Valley, three sites located near population centers have excellent potential for furure development. These include sites on vorthern Adak Island near the Adak Naval Station, sites on northern Atka Island near the Atka village, and Hot Springs Bay, near Akutan village. Development of the latter site is particularly attractive because of its accessibility from the sea and its proximity $(4 \mathrm{~km})$ to Akutan Harbor and village. Other sites that warrant consideration for future development are the Geyser Bigbt geothermal area on Umnak Island, Glacier Valley in the Makushin geothermal area, and the Mount Spurr area, west of Anchorage. Land at these sites is owned by Native corporations or by the state of Alaska. High-temperature ( $\mathrm{T}>150^{\circ} \mathrm{C}$ ) hydrothermal systems that are capable of producing electric power have been identified at each of these sites.

\section{ACKNOWLEDGMENTS}

We thank Eugene Wescott, Donald Turner, John Reeder, Robert Poreda, Malcolm Robb, and many others, too numerous to list, for their valuable assistance in performing field work (sometimes under extraordinarily adverse conditions); Cathy Janik, William Evans, John Welhan, and many others who helped perform lab analyses; and our many colleagues for sharing and discussing their ideas on geothermal resources. We also thank Howard Ross and Joseph Moore (University of Utah Research Institute), Milton Wiltse (DGGS), and Robert Forbes (DGGS and University of Alaska, Fairbanks) for their technical reviews and helpful suggestions for improving this report. We wish also to acknowledge Nori Bowman for the cartography of the colored sheets. Punding for this project was provided in part by a grant from the U.S. Department of Energy (Grant DE-FG0788D12744). Any opinions, findings, conclusions, or recommendations expressed herein are those of the authors and do not necessarily reflect the views of the U.S. Department of Energy.

\section{REFERENCES CITED}

Alaska Volcano Observatory, 1993, Mt. Spurr's eruption: EOS, Transactions, American Geophysical Union, v. 74, no. 19, p. 217, 221-222.

Ballard, Sanford, Cartigan, C.R., and McConnell, V.S., 1991, Shallow conductive component of heat flow near Novarupta Dome, Katmai,
Alaska: Geopbysical Research Letters, v. 18. no. 8, p. 1529-1532.

Barnes, Ivan, and McCoy, G.A., 1979. Possible role of mantle-derived $\mathrm{CO}_{2}$ in causing two "phreatic" explosions in Alaska: Geology, v. 7, no. 9. p. 434-435.

Beikman, H.M., 1974a, Preliminary geologic map of the southwest quadrant of Alaska: U.S. Geological Survey Miscellaneous Field Studies Map MF-611, scale 1:1,000,000.

1974b, Prelimirary geologic map of the southeast quadrant of Alaska: U.S. Geological Survey Miscellaneous Field Studies Map MF-612, scale 1:1,000,000.

1975, Preliminary geologic map of the Alaska Peninsula and Aleutian Islands: U.S. Geological Survey Miscellaneous Field Studies Map MF-674, scale 1:1,000,000.

1980. Geologic map of Alaska: U.S. Geological Survey, Professional Paper 171, scale $1: 2,500,000$.

Black, R.P., 1975, Late Quateroary geomorphic processes: Effects on the ancient Aleuts of Umuak Island in the Aleutians: Arctic, v. 28, no. 3, p. 159-169.

Brook, C.A., Mariner, R.H., Mabey, D.R., Swanson, James, Guffanti, Marianoe, and Muffler, L.J.P., 1979, Hydrothermal convection systems with reservoir temperatures $>90^{\circ} \mathrm{C}$, in Muffler, L.J.P., ed., Assessment of geothermal resources of the United States-1978: U.S. Geological Survey Circular 790, p. 18-85.

Burk, C.A., 1965, Geology of the Alaska Peninsulaisland are and continental margin. pts. 1, 2, and 3: Geological Society of America Memoir 99, 250 p., 3 pls., scaie 1:500,000 and 1:250,000.

Byers, F.M., Jr., 1959, Geology of Umnak and Bogoslof Islands, Aleutian Island, Alaska: U.S. Geological Survey Bulletin 1028-L, p. 107-367.

Byers, F.M., Jr., and Brannock, W.W., 1949, Volcanic activity on Umnak and Great Sitkin Islands, 1946-1948: American Geophysical Union Transaction, v. 30, no. 5, p. 719-734.

Casadevall, T.J., 1990. The 1989-1990 eruption of Redoubc Volcano, Alaska: Impacts on aircraft operations in the vicinity of Anchorage [abs.]: American Geophysical Union Transactions, v. 71, no. 43. p. 1701.

Coats, R.R., 1950, Volcanic activity in the Aleutian arc: U.S. Geological Survey Bulletin 974-B, p. 1-47. 
1956a, Geology of northem Adak Island, Alaska: U.S. Geological Survey Bulletin 1028-C, p. 45-67.

1956b, Geology of northern Kanaga Island, Alaska: U.S. Geological Survey Bulletin 1028-D, p. 69-81.

1956c, Reconnaissance geology of some western Aleutian Islands, Alaska: U.S. Geological Survey Bulletin 1028-E. p. 82-100.

1959, Geological reconnaissance of Semisopochnoi Island, western Aleutian Islands, Alaska: U.S. Geological Survey Bulletin 1028-O, p. 447-519.

Craig, H.A., 1961, Isotopic variations in meteoric waters: Science, v. 133, p. 1702.

Dall, W.H., 1870, Alaska and its resources: Boston, Lee and Shepard, 627 p. (Reprinted 1970, Arno and New York Times Press, American Environmental Studies series.)

D'Amore, Franco, and Panichi, C.R., 1980, Evaluation of deep temperature of hydrothermal systems by a new gas geothermometer: Geochimica et Cosmochimica Acta, v. 44, p. 549-556.

Eakins, G.R., 1970, Mineralization near Stepovak Bay. Alaska Peninsula, Alaska: Fairbanks, Alaska Division of Mines and Geology, Special Report 4, $12 \mathrm{p}$.

Penner, C.N., 1930, Mount Katmai and Mount Mageik: Zeitschrift für Vulkanologie, v, 13, p. 1-24.

Foillac, C., and Michard, G., 1981, Sodium/lithium ratio in water applied to geothermometry of geothermal reservoirs: Geothermics, v. 10, no. 1, p. 55-70.

Fournelle, John, 1990, Shishaldin, Isanotski, and Roundtop Volcanoes, in Wood, C.A., and Kienle. Jurgen, eds., Volcanoes of North America: New York, Cambridge University Press, p. 48-50. 1991, Geology and geochemistry of Fisher Caldera, Unimak Island. Aleutians: Initial results [abs.]: American Geophysical Union Transactions, v. 71 , no. 43 , p. 1698-1699.

Fournier, R.O., 1981, Application of water chemistry to geothermal exploration and reservoir engineering, in Rybach, L., and Muffler, L.J.P., eds., Geothermal systems: Principles and case histories: New York, Wiley, p. 109-143.

Fournier, R.O., and Potter, R.W. II, 1979, A magnesium correction for the $\mathrm{Na}-\mathrm{K}-\mathrm{Ca}$ geothermometer: Geochimica et Cosmochimica Acta, v. 43, p. 1543-1550.
1982, An equation correlating the solubility of quartz in water from $25^{\circ}$ to $900^{\circ} \mathrm{C}$ at pressures up to 10,000 bars: Geochimica et Cosmochimica Acta, v. 46, p. 1969-1973.

Fritz, Peter, and Fontes, J. Cb., 1980, eds., Handbook of environmental isotope geuchemistry, v. 1: New York, Elsevier, 545 p.

Giggenbach, W.F, 1987, Redox processes governing the chemistry of fumarolic gas discharges from White Island, New Zealand: Applied Geochemistry, v. 2, p. 143-162.

1988, Geothermal solute equilibria derivation of Na-K.Ca geoindicators: Geochimica et Cosmochimica Acta, v. 52, p. 2749-2765.

Giggenbach, W.F., and Goguel, R.L., 1989, Collection and analysis of geothermal and volcanic water and gas discharges: Petone, New Zealand, Department of Science and Industrial Research, Chemistry Division, Report CD 3401, $81 \mathrm{p}$.

Grewingk, C., 1850, Beitrag zur Kenntnisse der orographischen und geognostischen Beschaffenheir de Nordwest-Kuste Amerikas mit den aliegenden Insein: Verhandlungen der Russich-Kaiserlichen Mineralogischen Gesellschalt zur St. Petersburg, Jahrgan 1848 ung 1849, p. 76-342.

Griggs, R.F., 1922, The Valley of Ten Thousand Smokes: Washington, D.C., National Geographic Society, $340 \mathrm{p}$.

Hildreth, Wes, 1990, Mageik. Trident, Novarupta, Falling Mountain, Cerberus, Katmai, and Griggs Volcanoes, in Wood, C.A., and Kienle, Jurgen, eds., Volcanoes of North America: New York, Cambridge University Press, p. 67-72.

Hrdlicka, A., 1945, The Aleutian and Commander Islands and their inhabitants: Philadelphia, Wister Institute of Anatomy and Biology, $630 \mathrm{p}$.

Jacob, K.H., 1986, Seismicity, tectonics, and geohazards of the Gulf of Alaska regions, in Hood, D.W., and Zimmerman, S.T., eds., The Gulf of Alaska, physical environment and biological resources: Washington, D.C., U.S. Department of Commerce. National Oceanic and Atmospheric Administration, and other organizations. U.S. Department of the Interior (Minerals Management Service), p. 145-184.

Juhle, R.W., 1955, Lliamna Volcano and its basement: U. S. Geological Survey Open-file Report 55-77, $74 \mathrm{p}$. 
Karzenstein, A.M., and Whelan, J.A., 1985, Geothermal potential of Adak Island, Alaska: China Lake, Califomia, Naval Weapons Center, NWC TP 6676, $92 \mathrm{p}$.

Keith, T.E.C., 1991, Fossil and active fumaroles in the 1912 eruptive deposits, Valley of Ten Thousand Smokes, Alaska: Joumal of Volcanology and Geothermal Research, v. 45, no. 3-4, p. 227-254.

Keith, TE.C., Thompson, J.M., Hutchinson, R.A.. White, L.D., 1992, Geochemistry of waters in the Valley of Ten Thousand Smokes region, Alaska: Joumal of Volcanology and Geothermal Research, v. 49, no. 2. p. 209-231.

Keller, A.S., and Reiser, H.N., 1959, Geology of the Mt. Katmai area. Alaska: U.S. Geological Survey Bulletin 1058-G, p. 261-298.

Kennedy, G.C., and Waldron, H.H., 1955, Geology of Pavlof Volcano and vicinity, Alaska: U.S. Geological Survey Bulletia 1028-A, p. 1-18.

Kharaka, Y.K., and Mariner, R.H., 1989, Chemical geothermometers and their application to formation waters from sedimentary basins, in Naeser, N.D., and McCulloch, T.H., eds., Thermal history of sedimentary basins: New York, Springer-Verlag, p. 99-117.

Kienle, Jurgen, 1990, Ukinrek maars, Augustine Volcano, and Buzzard Creek volcanics, in Wood, C.A., and Kienle, Jurgen, eds., Volcanoes of North America: New York, Cambridge University Press, p. 65-66, 79-80, 85-86.

Kienle, Jurgen, Kyle, P.R., Self, Stephen, Motyka, R.J., and Lorenz, Volker, 1980, Ukinrek maars, Alaska, 1. April 1977 eruption sequence, petrology, and tectonic setting: Journal of Volcanology and Geothermal Research, v. 7 , no. 1, p. 11-37.

Kienle, Jurgen, and Nye, C.J., 1990, Volcano tectonics of Alaska, in Wood, C.A., and Kienle, Jurgen, eds., Volcanoes of North America: New York, Cambridge University Press, p. 8-16.

Kienle, Jurgen, and Swanson, S.E., 1983, Volcanism in the eastern Aleutian arc: Late Quaternary and Holocene centers, tectonic setting, and petrology: Journal of Volcanology and Geothermal Research, v. 17, nos. 1-4. p. 393-432.

Kienle, Jurgen, Swanson, S.E., and Pulpan, Hans, 1983. Magmatism and subduction in the eastern Aleutian arc, in Shimozuru, D., and Yokoyama, I., eds., Arc volcanism: physics and Tectonics:
Tokyo, Terra Scientific Publishing Company, p. $29,41$.

Kodosky, L.G, 1989, Surface mercury geochemistry as a guide to volcanic vent structure and zones of high heat flow in the Valley of Ten Thousand Sinokes, Katmai National Park, Alaska: Joumal of Volcanology and Geothermal Research, v. 38 , no. $3 / 4$, p. $227-242$.

Kodosky, L.G., and Keskinen, Mary, 1990, Fumarole distribution, morphology, and encrustation mineralogy associated with the 1986 eruptive deposits of Mount St. Augustine, Alaska: Bulletin of Volcanology, v. 52, no. 3, p. 175-185.

Kodosky, L.G., Motyka, R.J., and Symonds, R.B., 1991, Fumarolic emissions from Mount St. Augustine, Alaska: 1979-1984 degassing trends. volatile sources, and their possible role in eruptive style: Bulletin of Volcanology, v. 53, no. 5 , p. 381-394.

Lawver, L.A., Lachenbruch, A.H., and Moses, T.H., Jr., 1979, Status of regional heat-flow studies in Alaska, in Johnson, K. M., and Williams, J. R., eds., U.S. Geological Survey in Alaska: Accomplishments during 1978: U. S. Geological Survey Circular 804-B, p. B5-B7.

Liss, S.A., Motyka, R.J., and Nye, C.J., 1988, Alaska geothermal bibliography: Alaska Division of Geological \& Geophysical Surveys, Report of Investigations 88-18, $44 \mathrm{p}$.

Luedke, R.G., and Smith, R.L., 1986, Map showing distribution, composition, and age of late Cenozoic volcanic centers in Alaska: U.S. Geological Survey Miscellaneous Investigations Map I-1091-F, 3 pls., scale 1:1,000,000.

Lyle, W.M., 1973, Geology and mineral evaluation of the Aniakchak River drainage, Alaska Peninsula: Fairbanks, Alaska Division of Geological \& Geophysical Surveys Open-Pile Report 26. 11 p.

Maddren, A.G., 1919, Sulphur on Unalaska and Akun Islands and near Stepovak Bay, Alaska: U.S. Geological Survey Bulletio 692-E, p. 283-298.

Mariner, R.H., Brook, C.A., Swartson, J.R., and Mabey, D.R., 1978, Selected data for hydrothermal convection systems in the United States with reservoir temperatures greater than or equal to $90^{\circ}$ C: U.S. Geological Survey Open-file Report 78-858, $475 \mathrm{p}$.

Markle, D.R., 1979, Geothermal energy in Alaska: Site data base and development status: Anchor- 
age, Alaska Division of Minerals \& Energy Management report to U.S. Department of Energy, DE-ACO3-79SF1049, 2 v., 545 p.

Marsh, B.D., 1990, Buldir, Gareloi, Moffett, Adagdak, Atka, and Amak, Volcanoes, in Wood. C.A., and Kienle, Jurgen, eds., Volcanoes of North America: New York, Cambridge University Press, p. 18, 22-23, 25-26, 29-31, 51.

McKenzie, W.F., and Truesdell, A.H., 1977. Geothermal reservoir temperatures estimated from the oxygen isotope compositions of dissolved sulfate and water from bot springs and shallow drill holes: Geothermics, v. 5, nos. 1-4, p. 51-62.

Miller, T.P., 1973, Distribution and chemical analyses of thermal springs in Alaska: U.S. Geological Survey Open-file Map 570, scale $1: 2,500,000$.

1990, Fisher, Dutton, Emmons, Hague, Pavlov, Pavlov Sister, Black Peak, Aniakchak, Ugashik, Peulik, and Iliamna volcanoes, in Wood, C.A., and Kienle, Jurgen, eds., Volcanoes of North America: New York, Cambridge University Press, p. 46-48, 51-54, 58-60, 63-64, 80-81.

Miller, T.P., and Davies, J.N., 1991, The 1989-1990 eruption of Redoubt Volcano: Chronology, character and effects [abs.], in Casadeval, T.J., ed,, First international symposium on volcanic ash and aviation safety, Seatte, Wash., 1991. Programs and abstracts: U.S. Geological Survey Circular 1065, p. 33.

Miller, T.P., and Smith, R.L., 1987, Late Quaternary caldera-forming eruptions in the eastern Aleutian arc, Alaska: Geology, v, 15, no. 5, p. 434438 .

Motyka, R.J., 1977, Katmai caldera: glacier growth, lake rise, and geothermal activity, in Short Notes an Alaskan Geology, 1977: Fairbanks, Alaska Division of Geological \& Geophysical Surveys Geologic Report 55, p. 17-22.

1978, Surveillance of Katmai caldera and Crater Lake, Alaska, 1977: Fairbanks, University of Alaska Geophysical Institute report to U.S. Park Service, contract P.O. PX9100-7-1009, 19 p.

1983, High-temperature hydrothermal resources in the Aleutian arc, in Alaska Geological Society Symposium on western Alaska geology and resource potential: Anchorage, 1982, Proceedings, Journal of Alaska Geological Society, v. 3, p. 87-99.

Motyka, R.J., Moorman, M.A., and Liss, S.A., 1981,
Assessment of thermal spring sites, Aleutian arc, Atka Island to Becharof Lake-preliminary results and evaluation: Fairbanks, Alaska Division of Geological \& Geophysical Surveys Open-file Report 144, 173 p.

1983, Geothermal resources of Alaska: Washington, D.C., Geophysical Data Center, National Oceanic and Atmospheric Administration, 1 pl., scale $1: 2,500,000$.

Motyka, R.J., Moorman, M.A., and Poreda, R.J., 1983, Progress report - thermal fluid investigations of the Makushin geothermal area: Alaska Division of Geological \& Geophysical Surveys Report of Investigations 83-15, $48 \mathrm{p}$.

Motyka, R.J., and Nye, C.J., eds., 1988, A geological, geochemical, and geophysical survey of the geothermal resources at Hot Springs Bay valley, Akutan Island, Alaska: Fairbanks, Alaska Division of Geological \& Geophysical Surveys, Report of Investigations 88-3, 115 p., 2 sheets, scale $1: 20,000$ and $1: 4,000$.

Motyka, R.J., and Nye, C.J., 1993, Thermal water and fumarole gas chemistry, Crater Peak, Mt. Spur, Alaska: Fairbanks, in Alaska Division of Geological \& Geophysical Surveys Shor Notes on Alaskan Geology, Special Report 113, p. $31-40$.

Motyka, R.J., Nye, C.J., Turner, D.L., and Liss, S.A., 1993. The Geyser Bight Geothermal area, Umnak Island, Alaska: Geothermics, v. 22, no. 4, p. 301-327.

Motyka, R.J., Queen, L.D., Janik, C.J., Sheppard, D.S., Poreda, R.J., and Liss, S.A., 1988, Pluid geochemistry and fluid-mineral equilibria in test wells and thermal-gradient holes at the Makushin geothermal area, Unalaska Island, Alaska: Fairbanks, Alaska Division of Geological \& Geophysical Surveys Report of Investigations 88-14, $90 \mathrm{p}$.

Muffler, L.J.P., ed., 1979, Assessment of geothermal resources of the United States-1978: U.S. Geological Survey Circular 790, $163 \mathrm{p}$.

Myers, J.D., 1990, Seguam, Amukta, Chagulak, Herbert, Carlisle, Cleveland. Chuginadak, Uliaga, and Kagamil Volcanoes, in Wood, C.A., and Kienle, Jurgen, eds., Volcanoes of North America: New York, Cambridge University Press, p. 31-37.

Newhall, C.G., and Dzurisin, Daniel, 1988, Historical unrest at large calderas of the world: U.S. Geological Survey Bulletin 1855, 2 v., $1308 \mathrm{p}$. 
Nye, C.J., 1990, Vsevidof, Recheschnoi, Okmok, Makushin, Gilbert, Spurr, Wrangell, Teller, Espenberg. Imunuk, Koyuk-Buckland volcanic centers, in Wood, C.A., and Kienle, Jurgen, eds., Volcanoes of North America: New York, Cambridge University Press, p. 37-40, 41-43, 44, 83-84, 88-89, 105-108.

Nye, C.J., Motyka, R.J., Turner, D.L., and Liss, S.A., 1992, Geology and geochemistry of the Geyser Bight geothermal area, Umnak Island, Aleutian Islands, Alaska: Fairbanks, Alaska Division of Geological \& Geophysical Surveys, Report of Investigations $92-1,85$ p., 2 sheets, scale $1: 24,000$.

Nye, C.J., Queen, L.D., and Motyka, R.J, 1984, Geologic map of the Makushin geothermal area, Unalaska Island, Alaska: Fairbanks, Alaska Division of Geological \& Geophysical Surveys Report of Investigations 84-3, 1 pl., scale $1: 24,000$.

Nye, C.J., and Turner, D.L., 1990, Petrology, geochemistry, and age of the Spurr volcanic complex, eastern Aleutian arc: Bulletin of Volcanology, v. 52, no. 3, p. 205-226.

Poreda, R.J., and Craig, Harmon, 1989, Helium isotope ratios in circum-Pacific volcanic ares: Nature, v. 338, p. 473-478.

Queen, L.D., 1989, Alteration, fluid inclusion, and water-rock equilibrium in the Makushin hydrothermal system, Unalaska Island, Alaska: Fairbanks, University of Alaska M.S. thesis, $128 \mathrm{p}$.

Reed, M.H., and Symonds, R.B., in press, Calculation of multi-component chemical equilibria in gassolid-liquid systems, pt. I: Calculation methods: American Joumal of Science.

Reeder, I.W., 1981, Initial assessment of hydrothermal resources of the Summer Bay region on Unalaska Island, Alaska: Geothermal Resources Council Transactions, v. 5, p. 123-126.

1982a, Hydrothermal resources of the northerm part of Unalaska Island, Alaska: Alaska Division of Geological \& Geophysical Surveys Open-file Report 163, 17 p.

1982b, Hydrothermal resources of the

Makushir Volcano region of Unalaska Island. Alaska: in Watson, S.T., ed., Conference on Circum-Pacific Eoergy and Mineral Resources, 3rd, Honolulu, 1982, Transactions, p.441-450.

Republic Geothermal, Inc., 1983, The Unalaska geothermal exploration project, phase IB: Final report to Alaska Power Authority, 160 p., 16 app., 9 pls., scale 1:24,000 and 1:50,000.

1984, The Unalaska geothermal exploration project, phase II: Final report to Alaska Power Authority, 104 p., 13 app. 1985, The Unalaska geothermal exploration project, phase III.: Final report to Alaska Power Authority, 105 p., 11 app.

Riehle, J.R., 1990, Yantarni, Chiginagak, Kialagvik, Hayes, and Edgecumbe Volcanoes, in Wood, C.A., and Kienie, Jurgen, eds., Volcanoes of North America: New York, Cambridge University Press, p. 60-63, 84-85, 93-93.

Sass, J.H., and Monroe, R.J., 1970, Heat flow from deep bore holes on two island arcs: Journal of Geophysical Research, v. 75, no. 23, p. 4378-4395.

Scholl, D.W., Vallier, T.L., and Stevenson, A.J., 1987. Geological evolution and petroleum geology of the Aleutian ridge, in Scholl, D.W., Grantz, Arthur, and Vedder, J.G., eds., Geology and resource potential of the continental margin of western North America and adjacent ocean basins - Beaufort Sea to Baja California: Houston, Tex., Circum-Pacific Council for Energy and Mineral Resources Earth Science Series, v. 6, p. 123-155.

SEAN, 1987, Scientific Event Alert Network Bulletia, v. 12, p. 9.

Sheppard, D.S., Janik, C.J., Keith, T.E.C., 1992, A comparison of gas chemistry of fumaroles on the 1912 ash flow sheet and on active stratovolcanoes, Katmai National Park, Alaska: Journal of Volcanology and Geothermal Research, v. 53, nos. 1-4, p. 185-197.

Simkin, Tom, Siebert, Lee, McClelland, Lindsay, Bridge, David, Newhall, C.G., and Latten, J.H., 1981, Volcanoes of the world: Smithsonian Institution, Hutchinson Ross Publishing Company, Stroudsberg, $232 \mathrm{p}$.

Simons, F.S., and Mathewson, D.E., 1955, Geology of Great Sitkin Island, Alaska: U.S. Geological Survey Bulletin 1028-B, p. 21-43.

Smith, R.L., and Shaw, H.R., 1975, Igneous-related geothermal systems, in White, D.E., and Williams, D.L., eds., Assessment of geothermal resources of the United States - 1975: U.S. Geological Survey Circular 726, p. 58-84.

1979, Igneous-related geothermal systems, in Muffler, L.J.P., ed., Assessment of geothermal resources of the United States 1978: U.S. Geological Survey Circular 790, p. 12-17. 
Smith, W.R., and Baker, A.A., 1924, The Cold BayChignik district,Alaska: U.S. Geological Survey Bulletin 755-D. p. 151-218.

Snyder, G.L., 1954, Eruption of Trident Volcano, Katmai National Mosiument, Alaska, FebruaryJune 1953: U.S. Geological Survey Circular 318, p. $318-324$

3959, Geology of Little Sitkin Island, Alaska: U.S. Geological Survey Bulletin 1028-H, p. 169-210.

Sorey, M.L., Nathenson, Manuel, and Smith, Christian, 1983, Methods for assessing lowtemperature geothermal resources, in Reed, M.J., ed., Assessment of low-temperature geothermal resources of the United States 1982: U.S. Geological Survey Circular 892, p. 17-29.

Spurr, J.E., 1900, A reconnaissance in southwestern Alaska in 1898: U.S. Geological Survey 20th Annual Report, v. 7. p. 43-263.

Swanson, S. E., 1990, Akutan, Pogromni, Westdaul, Kejulik, Martin, Snowy, Denisom, Steller, Kukak, Devils Desk, Kaguyak, Fourpeaked, and Douglas Volcanoes, in Wood, C.A., and Kienle, Jurgen, eds., Volcanoes of North America: New York, Cambridge University Press, p. 43-44, 44-46, 66-67, 73-78.

Symonds, R.B., Rose, W.I., Gerlach, T.M., Briggs, P.H., and Harmon, R.S., 1990, Evaluation of gases, condensates, and $\mathrm{SO}_{2}$ emissions from Augustine Volcano, Alaska: The degassing of a Cl-rich volcanic system: Bulletin of Volcanology, v. 52 , no. 5 , p. $355-374$.

Truesdell, A.H., and Hulston, J.R., 1980, Isotopic evidence on environments of geothermal systems, in Friz, Peter, and Fontes, J.Ch., eds., Handbook of environmental isorope geochemistry. v. 1: New York, Elsevier, p. 179-226.

Turner, D.L., Forbes, R.B., Albanese, M.D., Lockhart, A.B., and Seed, S.M., 1980 , Geothermal resources of Alaska: Fairbanks, University of Alaska Geophysical Institute Report UAG-R-279, 19 p., 2 pls, scale 1:2,500,000.
Turner, D.L., and Wescott, E.M., 1985, Geothermal energy resource investigations at Mt. Spurr, Alaska: Fairbanks, University of Alaska, Geophysical Institute Report UAG-R-308, 105 p., 4 sheets, scale 1:63,360; 1:25,000.

Waldron, H.H., 1961, Geologic reconnaissance of Frosty Peak Volcano and vicinity, Alaska: U.S. Geological Survey Bulletin 1028-T, p. 677-708.

Waring, G.A., 1917, Mineral springs of Alaska: U.S. Geological Survey Water-Supply Paper 418. $114 \mathrm{p}$.

Wescott, E.M., Witte, Witliam, Turner, D.L., and Petzinger, Becky, 1988, Geophysical surveys of Hot Springs Bay valley, Akutan Island, Alaska, in Motyka, R.J., and Nye, C.J., eds., A geological, geochemical, and geophysical survey of the geothermal resources at Hot Springs Bay Valley, Akutan Island, Alaska: Fairbanks, Alaska Division of Geological \& Geophysical Surveys, Report of Investigations 88-3, p. 39-66, 2 pls., scale $1: 20,000$ and $1: 4,000$.

White, D.E., and Williams, D.L., 1975, Assessment of geothermal resources of the United States 1975: U.S. Geological Survey Circular 726. $155 \mathrm{p}$.

Wilson, F.H., 1990, Kupreanof volcano, in Wood, C.A., and Kienle, Jurgen, eds., Volcanoes of North America: New York, Cambridge University Press, p. 55-56.

Wood, C.A., and Kienle, Jurgen, 1990, Volcanoes of North America: New York, Cambridge University Press, $354 \mathrm{p}$.

Yount, M.E., 1990, Dana, Veniaminof, and Redoubt Volcanoes, in Wood, C.A., and Kienle, Jurgen, eds., Volcanoes of North America: New York, Cambriage University Press, p. 54-55, 56-58, 81.82 .

Yount, M.E., Wilson, F.H., and Miller, J.W., 1985, Newly discovered Holocene volcanic verts, Port Moller and Stepovak Bay quadrangles, in Bartsch-Winkler, S, and Reed, K. M., eds., U.S. Geological Survey in Alaska: Accomplishments during 1983: U.S. Geological Survey Circular 945, p. 60-62. 